\title{
ANALISIS LAJU PERTUMBUHAN DAN KONTRIBUSI PAJAK HOTEL DAN PAJAK RESTORAN PADA PENDAPATAN ASLI DAERAH (PAD) KOTA SURABAYA
}

(Studi Kasus di Pemerintahan Kota Surabaya)

\author{
Ita Aprilia \\ UIN Sunan Ampel Surabaya | itaaprilia96@gmail.com
}

\begin{abstract}
Abstrak: kegiatan pemungutan pajak yang hakikatnya merupakan kontribusi wajib kepada daerah yang bersifat memaksa. Berdasarkan hasil penelitian menjelaskan bahwa wujud nyata dari pemenuhan hak untuk setiap daerah Kabupaten/Kota dalam melaksanakan otonomi daerah secara mandiri dengan melakukan penggalian sumber dana Pendapatan Asli Daerah yang dianggap mampu mengelolah dan pengalokasiannya. Dana Pendapatan Asli Daerah diperoleh dari pajak yang merupakan biaya wajib yang harus dibayarkan setiap warga negara yang salah satu jenisnya adalah pajak hotel dan pajak restoran. Sektor pajak daerah merupakan sektor yang sangat mempengaruhi kondisi keuangan pemerintah daerah Kota Surabaya, punggutan pajak yang dilakukan oleh pemerintah Kota Surabaya digunakan untuk mengatur perekonomian Kota Surabaya. Pada penelitian ini menjelaskan bagaimana kontribusi dari pajak hotel dan restoran terhadap Pendapatan Asli Daerah. Penerapan dana dan anggaran Pendapatan Asli Daerah diharapkan dapat meningkatkan dan melaksanakan program kerja untuk pembangunan fisik dan non fisik di Kota Surabaya dapat terealisasikan dengan bagus. Dalam kegiatan pemunggutan pajak daerah dan realisasinya terdapat tahapan pertanggungjawaban dengan adanya surat pertanggungjawaban dan sudah tersampaikan kepada inspektorat pajak dengan tepat. Dalam perwujudan pembangunan daerah sudah efektif karena memperbaiki pembangunan kota sesuai dengan kebutuhan dan sudah dapat menerapkan Otonomi Daerah dalam wilayahnya.
\end{abstract}

Keywords: kontribusi; pajak hotel dan pajak restoran; pendapatan asli daerah; pembangunan daerah. 


\section{Pendahuluan}

Pajak daerah dan retribusi daerah merupakan salah satu indikator yang dapat membantu pemerintah dalam bidang menggali sumber penghasilan daerah, dengan adanya pajak daerah dan retribusi daerah hubungan antara pemerintah pusat dan pemerintah daerah bisa berkerja sama dengan baik melalui asas desentralisasi. ${ }^{1}$ Pelaksanaan tentang pajak daerah dan retribusi daerah sudah tercantum pada UU No.34 tahun 2000 dan UU No.23 Tahun 2004 tentang pemerintah di wilayah daerah. Undangundang tersebut lebih khusus membahas tentang otonomi daerah di bidang administrasi pemerintah ataupun dalam hal hubungan keungan antara pemerintah pusat dan pemerintah daerah. Untuk mendapatkan pencapaian otonomi daerah yang sejalan dengan tujuan maka pemerintah harus memberikan dan mengutamakan pembinaan dengan cara riset atau penelitian dan pengembangan yang dapat mencapai suatu perencanaan dan tidak luput dari pengevaluasian. Pemerintah juga wajib menyediakan fasilitas untuk kemudahan dalam melaksanakan otonomi dengan bagus dan efisien. Pemerintahan pusat juga mengharapkan pemerintahan daerah mampu mengali sumber dana atau keuangan untuk memenuhi kebutuhan pembiayaan. Melalui pendapatan asli daerah (PAD) kebutuhan pembiayaan pembangunan dan anggaran pemerintah disetiap daerah bisa terpenuhi.

Komponen pajak daerah dan retribusi daerah yang dapat digali dan dijadikan sebagai komponen pendapatan daerah adalah dengan menerapkan pajak daerah yang sesuai dengan UndangUndang yang telah ditetapkan oleh pemerintah. Pajak hotel dan restoran merupakan salah satu komponen pajak daerah yang dananya diperoleh dari biaya pelayanan hotel pada pengunjung hotel. Dari pajak hotel dan restoran dapat membantu pendapatan asli daerah disetiap tahunnya.

Pendapatan asli daerah (PAD) merupakan pendapatan suatu daerah yang di dapat dan bersumber dari punggutan-punggutan yang dilakukan sendiri oleh pemerintah daerah. Sumber pendapatan asli daerah berpotensial yang harus digali secara

${ }^{1}$ Irsyandi Octovido, Nengah Sudjana dan Devi Farah Azizah “Analisis Efektivitas dan Kontribusi Pajak Daerah Sebagai Sumber Pendapatan Asli Daerah Kota Batu" Vol. 15 No. 1 (2014). Hal 1 
maksimal sesuai dengan ketentuan yang berlaku, yang termasuk komponen dalam pendapatan asli daerah adalah retribusi daerah dan pajak daerah yang menjadi hal utama sumber pemunggutan dana pendapatan asli daerah. ${ }^{2}$ Sumber pendanaan yang diperoleh pemerintah daerah adalah pendapatan asli daerah yang bersumber dari hasil pajak daerah, hasil retribusi daerah, hasil perusahaan milik daerah (hasil pengelolaan kekayaan daerah) dan pendapatan asli daerah yang sah. Selain itu juga dana PAD juga bersumber dari dana perimbangan dan pinjaman daerah. Dana perimbangan merupakan dana yang berasal dan bersumber dari pendapatan APBN yang diberikan kepada daerah yang gunanya untuk membiayai dan mendanai kebutuhan daerah dalam pelaksanaan desentralisasi.

Kota Surabaya merupakan Kota terbesar di Jawa Timur dan salah satu Kota besar sebagai pusat perekonomian masyarakat Jawa timur. Kota Surabaya termasuk salah satu daerah otonom yang melaksanakan pembangunan dan menyelenggrakan pemerintahan untuk jangka pendek ataupun jangka panjang. Keunggulan lain dari Kota Surabaya adalah terdapat banyak fasilitas-fasilitas infrastruktur yang cukup lengkap, apalagi disetiap tahun banyak pembangunan hotel dan restoran, hal ini menjadikan potensi yang sangat bagus bagi peningkatan pendapatan asli daerah. Untuk merealisasikan pembangunan dan peemerintahan maka pemerintah daerah Kota Surabaya membutuhkan tersedianya dana yang cukup besar, selain itu harus ada kekuatan dari pemerintah daerah Kota Surabaya sendiri selain bantuan dari pemerintah pusat. Oleh karena itu Pemerintah Kota Surabaya harus mengoptimalkan sumber pendanaan dan penerimaan daerah yang salah satunya adalah dari pendapatan asli daerah (PAD).

\section{Metode Penelitian}

Pada penelitian ini data yang dikumpulkan berasal dari beberapa data antara lain data arsip Kota Surabaya mengenai gambaran umum pemerintahan Kota Surabaya, data penerimaan Pendapatan Asli daerah Kota Surabaya yang dusah terealisasi dan data penerimaan pajak hotel dan pajak restoran di Kota Surabaya.

\footnotetext{
${ }^{2}$ Ronald Bua Toding. “Analisis Potensi dan Efektivitas Pemungutan Pajak Hotel dalam Meningkatkan Pendapatan Asli Daerah Kota Palangkaraya" 4 no. 1 (2016) hal : 2
} 
Jenis sumber data yang didapatkan oleh penulis adalah data primer dan data sekunder. Data primer merupakan data yang diperoleh dari wawancara secara langsung antar narasumber dan penulis dan data sekunder didapatkan dari arsip-arsip Pemerintahan Kota Surabaya.

Teknik pengumpulan data melalui wawancara dilakukan lansung dalam memperoleh informasi yang data tersebut digali dari sumber yang bersangkutan. Teknis analisis data pada penelitian ini menggunakan penelitian kualitatif dengan permasalan pertama adalah bagaimana laju pertumbuhan pajk hotel dan pajak restoran yang dilakukan dengan cara wawancara seberapa dampaknya yang diberikan kontribusi pajak hotel dan pajak restoran di Pemerintahan Kota Surabaya. Permasalah kedua untuk mengetahui bagaiman kontribusi pajak hotel dan restoran pada pendapatan asli daerah yang dilakukan dengan wawancara dan pengumpulan data yang diperoleh di Badan Pengelolaan Keuangan dan Pajak Daerah Kota Surabaya.

\section{Analisis Data}

Pajak daerah pada hakikatnya merupakan kontribusi wajib kepada daerah terutang oleh orang pribadi atau badan yang bersifat memaksa berdasarkan Undang-Undang, dengan masyarakat membayar pajak tersebut dengan tidak langsung mendapatkan imbalan langsung tetapi digunakan untuk keperluan daerah dan untuk kemakmuran masyarakat. Penanggung jawab pajak ditujukan kepada orang pribadi atau badan yang bertanggung jawab atas pembayaran pajak termasuk menjalankan hak dan kewajiban wajib pajak menurut peraturan perundang-undangan perpajakan.

Wujud nyata dari pemenuhan hak untuk setiap daerah Kabupaten/Kota dalam melaksanakan otonominya secara mandiri dengan melakukan penggalian dana Pendapatan Asli Daerah yang dianggap mampu mengelolah dan mengalokasiannya. Hal ini dilakukan supaya dapat meningkatkan peran Pemerintah Daerah tingkat Kabupaten/Kota dalam memberikan pelayanan yang lebih baik dalam menjalankan otonomi daerahnya sendiri, sehingga dapat meningkatkan kesejahteraan masyarakat serta mempercepat laju pertumbuhan ekonomi dan pembangunan nasional.

Dana yang bersumber dari pajak daerah dan retribusi daerah yang dialokasikan untuk memfasilitasi kebutuhan masyarakat 
dalam mendanai keperluan tata kota dengan rangka penyelenggaraan pemerintah daerah Kabupaten/Kota dan melaksanakan pembangunan daerah serta meningkatkan pelayanan masyarakat. Anggaran ini diperoleh dari punggutan pajak daerah yang sudah ditetapkan berdasarkan UndangUndang yang berlaku.

Pada penerapan dana anggaran Pendapatan Asli Daerah diharapkan mampu meningkatkan dari segala bidang baik itu dari segi fisik berupa pembangunan-pembangunan infrastruktur atau berupa layanan sosial kepada masyarakat. Dari segi fisik yang berupa pembangunan-pembangunan fasilitas kota meliputi pembangunan jalan raya, pembangunan gorong-gorong, pemapingan di jalan kampung, pembuatan taman kota, rumah sakit, pembangunan sarana olahraga dan lainnya, dan untuk penerapan secara layanan sosial meliputi pembebasan pembayaran SPP dari tingkat SD sampai tingkat SMP, pemberian makan untuk lansia dan masyarakat tidak mampu, dan layanan kesehatan untuk masyarakat.

Peningkatan laju pertumbuhan pajak hotel dan pajak restoran di dukung oleh kesadaran masyarakat untuk membayar pajak. Apalagi untuk pajak hotel dan restoran sistem pemungutan pajaknya sesuai dengan teori sistem pemungutan pajak Self Assessment System yaitu pada sistem ini wajib pajak dapat menentukan sendiri berapa besarnya pajak yang terutang yang harus dibayar oleh pelaku wajib pajak. Sistem ini segala halnya ditentukan sendiri oleh yang berwenang wajib pajak itu sendiri. Pada sistem pemungutan pajak Self Assessment System memiliki beberapa ciri-ciri, diantaranya wajib pajak harus aktif dalam arti aktif mulai dari pelaporan pajak dan pendaftaran ke badan pajak, menghitung, dan menyetor secara mandiri, memiliki wewenang menetukan besarnya pajak yang terutang pada wajib pajak, tidak ada campur tangan dari pemerintah hanya mengawasi saja dan bertindak jika ada perusahaan hotel dan restoran yang melakukan kecurangan dalam arti tidak melakukan pelaporan pajaknya yang terutang kepada badan pajak maka dengan terjadi hal seperti itu pemerintah memiliki wewenang untuk melakukan peneguran.

Pemerintahan Kota Surabaya harus melakukan berbagai upaya untuk meningkatkan penerimaan pajak hotel dan pajak restoran dan mengurangi hambatan yang terjadi melalui 
peningkatan kinerja pemungutan pajak dalam arti penyempurnaan pendataan, penetapan dan penagihan yang diatur sehingga menjamin kelancaran, ketetapan alur penerimaan atas hasil pemungutan ke kas daerah. Menyesuaikan antara laporan yang diserahkan oleh wajib pajak dengan kenyataan yang sebenarnya dilapangan. Pemerintahan Kota Surabaya memaksimalkan pendapatan pajak daerah berkaitan dengan pencarian data yang belum ada, penambahan jumlah wajib pajak dan melakukan sosialisasi melalui media atau lain sebagainya.

\section{Kesimpulan}

Laju pertumbuhan pajak hotel dan restoran setiap tahunnya mengalami peningkatan, hal tersebut di faktori oleh minatnya masyarakat membangun bisnis di bidang properti dan bidang makanan. Jika setiap tahun bertambahnya pembangunanpembangunan perhotelan dan restoran otomatis pendapatan pajak daerah dari pajak hotel dan pajak rsetoran akan meningkat. Dengan adanya dana dari pajak yang meningkat maka dapat membantu Pendapatan Asli Daerah yang berdampak dalam membantu kinerja pemerintah Kota Surabaya dalam meningkatkan kesejahteraan masyarakat Kota Surabaya. Penganggaran Pendapatan Asli Daerah di Kota Surabaya merupakan suatu proses dengan urutan pengendalian, pengaturan dan mengurus penyelenggraan anggaran Pendapatan Asli Daerah yang digunakan untuk keperluan operasional pemerintah kota dan meningkatkan pelayanan masyarakat yang dimulai dari perencanaan sampai dengan pertangunggjawaban. Penganggaran dana bertujuan untuk meningkatkan kesejahteraan masyarakat di Kota Surabaya agar dapat tumbuh dan berkembang secara baik dan terarah yang sesuai dengan perencanaan pembangunan dan program-program pemerintah berdasarkan peraturan-peraturan yang berlaku.

Pengelolaan dana Pendapatan Asli Daerah diharapkan dapat memberikan dampak terhadap masyarakat dengan adanya otonomi daerah yang memberikan wewnang kepada suatu daerah memanfaatkan apa yang dimiliki agar mendapatkan sumbersumber dana yang bisa digali, dengan adanya hal itu diharapkan dapat meningkatkan kesejahteraan masyarakat berupa peningkatan layanann masyarakat dan pembangunanpembangunan infrastrutur kota. Selain itu juga diharapkan 
mampu meningkatkan pembangunan nasional berdasarkan otonomi daerah. Pembangunan fisisk berupa infrastruktur dan tata kota di Kota Surabaya dengan memanfaatkan dan Pendapatan Asli Daerah berjalan dengan baik sesuai dengan aturan yang berlaku. Pembangunan nyata dari pembangunan fisik tersebut berupa pembangunan jalan atau pelebaran jalan, pembangunan taman-taman kota, penataan tata kota dan lain sebagainya.

\section{Daftar Pustaka}

Betty Rahayu. “ Analisis Potensi Pajak Hotel Terhadap Realisasi Penerimaan Pajak Hotel di Kabupaten Gunungkidul" skripsi (2016):

Christina Ratih P. “Analisis Kontribusi Pajak Hotel dan Retoran Terhadap Pendapatan Asli Daerah (Studi Kasus di Pemerintahan Kota Yogyakarta)" skripsi (2010)

Diaz Ardhiansyah, Sri Mangesti Rahayu, Achmad Husaini. “Analisis Potensi Pajak Hotel dan Pajak Restoran dan Kontribusinya Terhadap Pendapaatan Asli Daerah (Studi Kasus pada Dinas Pendapatan Daerah Kota Batu Tahun 2011-2013)"14, no.1 (2014)

Edward W Memah. "Efektivitas dan Kontribusi Penerimaan Pajak Hotel dan Restoran Terhadap PAD Kota Manado"1, no. 3 (2013)

Irsandy Octovido, Nengah Sudjana, dan Devi Farah Azizah. "Analisis Efektivitas dan Kontribusi Pajak Daerah Sebagai Sumber Pendapatan Asli Daerah Kota Batu (Studi Pada Kasus Pendapatan Daerah Kota Batu Tahun 2009-2013)"15, no.1 
Ita Aprilia

Siti Kurnia Rahayu, Ely Suhayati. Perpajakan Teori dan Teknis Perhitungan. Yogyakarta: Graha Ilmu, 2010

https://www.Surabaya.go.id

Peraturan Daerah Kota Surabaya Nomor 1 Tahun 2017

Peraturan Walikota Surabaya Nomor 70 Tahun 2016

Data Dinas Pendapatan dan Pengelolaan Keuangan Kota Surabaya

Ibu Dra. Nurhayati, MM. Wawancara, 24 Juni 2019

Bapak Budianto, Wawancara, 31 Mei 